\title{
Proximate and Sensory Properties of Wheat-Cocoyam (Colocasia Esculenta) Composite Bread
}

\author{
Bosede Adelola Orhevba and Yahaya Ndanaimi
}

\section{ABSTRACT}

\begin{abstract}
In this study, samples of composite breads were produced from wheat and cocoyam flour blends using D-optimal design mixture, in the following proportions: 95:5, 90:10, 85:15. Bread sample which contained $100 \%$ wheat flour was also produced and this served as the control. The bread samples obtained were subjected to proximate and sensory analysis. The following results were obtained for the whole wheat flour bread: moisture $(27.65 \%)$, protein $(11.33 \%)$, crude fibre $(0.59 \%)$, ash content $(0.78 \%$, fat $(8.19 \%)$ and carbohydrate content $(53.69 \%)$, respectively. While the composite bread samples had the moisture, protein, crude, ash, fat and carbohydrate in the following ranges:17.93-23.63\%, 7.16-10.83\%, 0.59-0.88\%, 0.47-0.98\%, 4.43$7.81 \%$ and $55.94-1.31 \%$, respectively. The sensory tests carried out on the bread samples indicated that there was no significant difference between the whole wheat bread and the composite bread samples for flavour, crumb appearance and taste. However, for texture, overall preference and crust colour properties of the bread samples, significant differences were observed. From the study, it can be concluded that wheat flour can be substituted with cocoyam flour and bread samples made from this combination (up to $15 \%$ cocoyam flour inclusion) were acceptable. It was observed that the $100 \%$ wheat flour bread is the most acceptable, followed by the $5 \%$ cocoyam flour composite bread samples. Usage of cocoyam flours in bread baking can contribute significantly to enhancing nutrition and curbing the rising cost of bread.
\end{abstract}

Keywords: Cocoyam flour, composite bread, D-optimal design mixture, proximate composition.

\section{INTRODUCTION}

According to [1], bread is a fermented baked product gotten from wheat flour, water, yeast, and salt through processes which include mixing, kneading, proofing, shaping, and baking.

Wheat flour is one of the vital ingredients in bread production due to the gluten it contains. [2] reported that this gluten (in wheat flour) accounts for the elasticity of the dough which aids in trapping the carbon dioxide generated by yeast during fermentation. Nevertheless, wheat is a temperate crop and will not thrive under tropical conditions [3], [4]. Nigeria and many other developing nations (who are majorly in the tropics) therefore have to import wheat or wheat flour to meet their confectionary needs.

According to [5] and [6], the Food and Agricultural Organization (FAO) in the 1960s encouraged research on composite bread in a bid to reduce the import dependency of developing countries. [7] also reported on the unique baking properties of wheat which no other crop has, hence, the many studies being carried out on composite flour; as many as 1200 studies by the year 1993 according to [8]. Composite flour can be defined as a mixture of flours, starches and other ingredients used to totally or partially substitute wheat flour in confectionary [9]. [10] defined composite flour as combination of wheat flour with other flours like cassava, maize, and soybean. [7] also defined composite flour as a combination of flours from starch tubers like cassava, potatoes, yam etc. or crops rich in protein like soybean and ground nut or cereals (maize, rice, millet, sorghum) with or without wheat flour.

In developing countries, composite flour is favourably considered due to the fact that it decreases the importation of wheat flour and boosts the use of locally available crops as flour [11]. In countries having crops other than wheat, it is considered economically beneficial to decrease or even abolish imports of wheat thereby meeting the needs of confectionary products by the utilization of locally grown crops [12].

Cocoyam (Colocasia esculenta) is highly nutritious and edible but underutilized. It belongs to the family, Araceae. According to [13], about 30-40 species of cocoyam have been identified, however, only 5-6 species produce edible parts. [14] reported that cocoyam is an under exploited and highly neglected crop in Nigeria, despite the fact that it is very nutritious.

Attempts are being made to investigate other sources of flour for combining wheat flour as well as enhance the nutritional value of baked foods. Thus, the need to identify nutritious, easily accessible, and underutilized crops like cocoyam. The result of this study would be a great relief to Nigerians in particular and Africans at large, who could not afford the high cost of wheat flour and its baked products. 
Inclusion of cocoyam flour into wheat flour for confectionary purposes will help to decrease reliance on imported wheat flour, reduce cost of confectionary products, increase affordability, and enhance the nutritional value of the products.

\section{MATERIALS AND METHODS}

\section{A. Materials}

Fresh tubers of cocoyam (Xanthosoma sagittifolium) used for the study were obtained from a farm in Minna. Wheat flour and other bread ingredients used for the study were obtained from a market in Minna, Niger State, Nigeria.

\section{B. Methods}

The cocoyam tubers were sorted to remove impurities. They were peeled with knife and washed. They were then cut into uniform sizes of $5 \mathrm{~mm}$ and divided into twenty equal samples. Each sample was weighed, labelled, and blanched in water bath maintained at constant temperature of $100{ }^{\circ} \mathrm{C}$ for 5 mins as reported by [15]. The blanched chips were spread on trays and dried in an oven at $77^{\circ} \mathrm{C}$ for 14 hours. The dried samples were ground into fine flour using a milling machine. The experimental design used for the study was the optimal mixture design of the response surface methodology (RSM). This generated 28 experimental runs (Table I). The independent variables were wheat flour, cocoyam flour, baking temperature and baking time, while the responses were moisture, fat, carbohydrates, protein, ash, and fibre contents.

TABLE I: EXPERIMENTAL DESIGN FOR THE WHEAT-COCOYAM BLENDS

\begin{tabular}{|c|c|c|c|c|c|c|}
\hline Samples & Run & $\begin{array}{c}\text { Wheat } \\
(\%)\end{array}$ & $\begin{array}{c}\text { Cocoyam } \\
(\%)\end{array}$ & $\begin{array}{c}\text { Baking } \\
\text { Temp } \\
\left({ }^{\circ} \mathrm{C}\right)\end{array}$ & $\begin{array}{c}\text { Baking } \\
\text { Time } \\
\text { (mins) }\end{array}$ & $\begin{array}{c}\text { Responses } \\
(\%)\end{array}$ \\
\hline A & 1 & 87.52 & 12.48 & 235 & 35 & \\
\hline B & 2 & 85 & 15 & 265 & 35 & \\
\hline $\mathrm{C}$ & 3 & 85 & 15 & 265 & 40 & \\
\hline D & 4 & 85 & 15 & 235 & 35 & \\
\hline $\mathrm{E}$ & 5 & 93.74 & 6.26 & 265 & 45 & \\
\hline $\mathrm{F}$ & 6 & 90 & 10 & 265 & 35 & \\
\hline $\mathrm{G}$ & 7 & 85 & 15 & 265 & 45 & \\
\hline $\mathrm{H}$ & 8 & 92.48 & 7.52 & 250 & 35 & \\
\hline I & 9 & 85 & 15 & 242.5 & 37.5 & \\
\hline $\mathrm{J}$ & 10 & 90 & 10 & 250 & 45 & \\
\hline $\mathrm{K}$ & 11 & 90 & 10 & 265 & 35 & \\
\hline $\mathrm{L}$ & 12 & 95 & 5 & 235 & 45 & \\
\hline M & 13 & 95 & 5 & 235 & 45 & \\
\hline $\mathrm{N}$ & 14 & 95 & 5 & 235 & 35 & \\
\hline $\mathrm{O}$ & 15 & 91.2 & 8.77 & 265 & 35 & \\
\hline $\mathrm{P}$ & 16 & 95 & 5 & 235 & 40 & \\
\hline Q & 17 & 90 & 10 & 265 & 35 & \\
\hline $\mathrm{R}$ & 18 & 95 & 5 & 235 & 45 & \\
\hline $\mathrm{S}$ & 19 & 95 & 5 & 250 & 40 & \\
\hline $\mathrm{T}$ & 20 & 90 & 10 & 235 & 35 & \\
\hline $\mathrm{U}$ & 21 & 95 & 5 & 235 & 35 & \\
\hline V & 22 & 85 & 15 & 250 & 40 & \\
\hline W & 23 & 95 & 5 & 250 & 45 & \\
\hline$X$ & 24 & 90 & 10 & 265 & 45 & \\
\hline $\mathrm{Y}$ & 25 & 86.26 & 13.74 & 265 & 45 & \\
\hline $\mathrm{Z}$ & 26 & 90 & 10 & 265 & 40 & \\
\hline $\mathrm{A}_{1}$ & 27 & 85 & 15 & 250 & 40 & \\
\hline $\mathrm{B}_{1}$ & 28 & 85 & 15 & 235 & 40 & \\
\hline Control & & 100 & & 235 & & \\
\hline
\end{tabular}

Wheat and cocoyam flours were combined based on the experimental design as shown in Table II.
TABLE II: DESIGN MATRIX FOR WHEAT-COCOYAM BLENDS

\begin{tabular}{cccc}
\hline \multirow{2}{*}{ Variables } & \multirow{2}{*}{ Unit } & \multicolumn{2}{c}{ Levels } \\
\cline { 3 - 4 } & & Low & High \\
\hline Cocoyam flour & $\%$ & 5 & 15 \\
Wheat flour & $\%$ & 85 & 95 \\
Baking Temperature & ${ }^{\circ} \mathrm{C}$ & 235 & 265 \\
Baking Time & Min & 35 & 45 \\
\hline
\end{tabular}

The methods employed for the preparation of the bread samples were according to the methods described by [15] with little modification (Table III).

TABLE III: INGREDIENTS USED FOR THE FORMULATION OF DOUGH PER

\begin{tabular}{ccc}
\multicolumn{3}{c}{ LOAF } \\
\hline Ingredients & Composition $(\mathrm{g})$ & Composition $(\%)$ \\
\hline Flour & 300 & 60 \\
Water & 165 & 33 \\
Sugar & 18 & 3.6 \\
Butter & 8 & 1.6 \\
Yeast & 5 & 1 \\
Vitamin C & 2 & 0.4 \\
Salt & 2 & 0.4 \\
\hline
\end{tabular}

\section{Bread Baking Process}

All the ingredients (Table III) were initially dry mixed in a bowl and later mixed with water until soft dough that can easily be handled was produced. During the mixing of ingredients for dough formulation, the flour composition ratio varied while other ingredients were kept constant. The straight dough method described by [16] was followed. The dough was baked in an electric oven at different temperatures and time as specified on Table II. After baking, the bread samples were cooled at room temperature. Dough proofing and composite bread samples are shown in Plates 1-4.

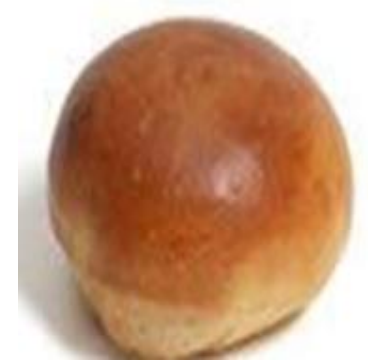

Plate 1. 95:5 (Wheat-Cocoyam) $235^{\circ} \mathrm{C}, 45$ mins.

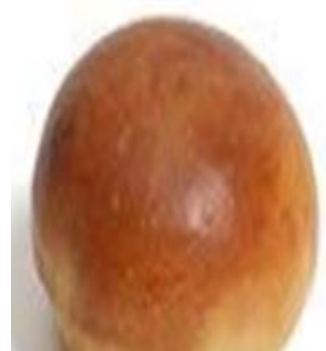

Plate 2. 95:5 (Wheat-Cocoyam) $235^{\circ} \mathrm{C}, 35$ mins.

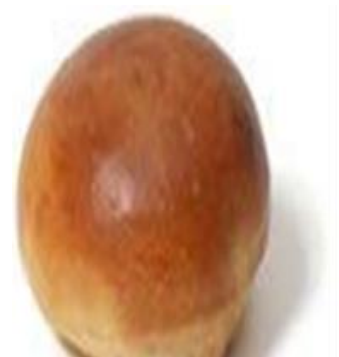

Plate 3. 85:15 (Wheat-Cocoyam) $265^{\circ} \mathrm{C}, 35$ mins 


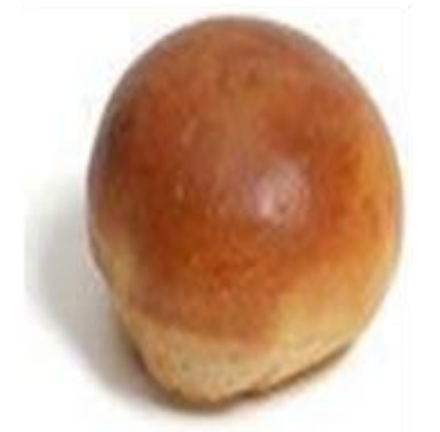

Plate 4. 85:15 (Wheat-Cocoyam) $250{ }^{\circ} \mathrm{C}, 40$ mins.

\section{Sensory Evaluation}

The sensory evaluation of the bread samples was carried out for consumer acceptance and preference using a 20-man trained panel (drawn from the university community). The following sensory properties were assessed: taste, flavour, crumb colour, crust colour, texture, and overall acceptability with the use of a nine-point Hedonic scale. On this scale, 1 represents "extremely dislike" while 9 represents "extremely like" respectively. Responses from the panellists were then analysed statistically.

\section{RESULTS AND DISCUSSION}

\section{A. Results}

The moisture, fat, carbohydrates, protein, ash, and fibre contents (proximate composition) and the mean sensory evaluation of the bread samples are shown in Tables IV and V.

\begin{tabular}{|c|c|c|c|c|c|c|}
\hline Samples & $\begin{array}{c}\text { Moisture } \\
(\%)\end{array}$ & $\begin{array}{c}\text { Protein } \\
(\%)\end{array}$ & $\begin{array}{c}\text { Crude } \\
(\%)\end{array}$ & $\begin{array}{l}\text { Ash } \\
(\%)\end{array}$ & $\begin{array}{l}\text { Fat } \\
(\%)\end{array}$ & $\begin{array}{c}\text { Carbohydrate } \\
(\%)\end{array}$ \\
\hline A & 21.07 & 8.32 & 0.66 & 0.85 & 5.25 & 65.47 \\
\hline B & 23.63 & 8.82 & 0.69 & 0.89 & 5.74 & 71.31 \\
\hline C & 21.09 & 7.16 & 0.65 & 0.96 & 5.8 & 69.17 \\
\hline $\mathrm{D}$ & 18.31 & 8.33 & 0.82 & 0.95 & 4.95 & 71.31 \\
\hline $\mathrm{E}$ & 22.65 & 10.72 & 0.6 & 0.49 & 5.08 & 67.54 \\
\hline $\mathrm{F}$ & 20.06 & 9.44 & 0.69 & 0.69 & 6.82 & 59.15 \\
\hline $\mathrm{G}$ & 17.97 & 8.34 & 0.83 & 0.95 & 5.05 & 70.84 \\
\hline $\mathrm{H}$ & 24.87 & 10.26 & 0.69 & 0.52 & 5.72 & 60.32 \\
\hline I & 19.51 & 8.42 & 0.78 & 0.98 & 4.43 & 67.13 \\
\hline $\mathrm{J}$ & 21.06 & 9.25 & 0.65 & 0.73 & 6.54 & 64.95 \\
\hline K & 20.54 & 8.794 & 0.66 & 0.73 & 7.02 & 65.34 \\
\hline $\mathrm{L}$ & 20.84 & 10.71 & 0.59 & 0.57 & 6.35 & 60.46 \\
\hline M & 18.82 & 10.75 & 0.6 & 0.49 & 7.15 & 55.94 \\
\hline $\mathrm{N}$ & 23.57 & 10.79 & 0.58 & 0.48 & 6.92 & 58.56 \\
\hline $\mathrm{O}$ & 19.74 & 9.52 & 0.65 & 0.58 & 6.68 & 60.05 \\
\hline $\mathrm{P}$ & 25.26 & 8.96 & 0.59 & 0.48 & 7.24 & 59.56 \\
\hline Q & 22.86 & 9.54 & 0.66 & 0.89 & 5.74 & 64.95 \\
\hline $\mathrm{R}$ & 21.66 & 10.03 & 0.65 & 0.48 & 7.81 & 54.6 \\
\hline S & 21.45 & 9.74 & 0.63 & 0.48 & 7.24 & 59.5 \\
\hline $\mathrm{T}$ & 20.05 & 9.16 & 0.76 & 0.65 & 6.72 & 64.33 \\
\hline $\mathrm{U}$ & 20.25 & 10.08 & 0.59 & 0.57 & 7.59 & 57.63 \\
\hline $\mathrm{V}$ & 21.66 & 8.62 & 0.85 & 0.89 & 4.49 & 67.54 \\
\hline W & 22.92 & 10.83 & 0.53 & 0.74 & 6.74 & 58.56 \\
\hline$X$ & 21.79 & 10.33 & 0.67 & 0.86 & 6.14 & 62.95 \\
\hline Y & 22.87 & 8.85 & 0.86 & 0.78 & 5.15 & 68.54 \\
\hline $\mathrm{Z}$ & 18.54 & 8.97 & 0.66 & 0.73 & 6.92 & 60.27 \\
\hline $\mathrm{A}_{1}$ & 18.23 & 8.46 & 0.86 & 0.96 & 5.62 & 70.84 \\
\hline $\mathrm{B}_{1}$ & 15.19 & 8.2 & 0.88 & 0.96 & 5.15 & 70.79 \\
\hline Control & 27.65 & 11.33 & 0.58 & 0.47 & 8.19 & 53.69 \\
\hline
\end{tabular}

TABLE V: MEANS OF SENSORY SCORE BASED ON 9-POINT HEDONIC SCALE

\begin{tabular}{ccccccc}
\hline Sample & Taste & Flavour & $\begin{array}{c}\text { Crust } \\
\text { colour }\end{array}$ & $\begin{array}{c}\text { Crumb } \\
\text { colour }\end{array}$ & Texture & $\begin{array}{c}\text { Overall } \\
\text { acceptability }\end{array}$ \\
\hline $\mathrm{A}$ & 8.33 & 7.33 & 8.33 & 6.67 & 6.33 & 7.50 \\
$\mathrm{~B}$ & 6.33 & 7.67 & 6.33 & 6.33 & 6.67 & 7.33 \\
$\mathrm{C}$ & 6.00 & 7.33 & 7.33 & 7.33 & 6.67 & 6.83 \\
$\mathrm{D}$ & 6.00 & 8.00 & 7.67 & 7.33 & 6.67 & 6.50 \\
$\mathrm{E}$ & 8.67 & 6.67 & 7.00 & 6.33 & 6.33 & 7.33 \\
$\mathrm{~F}$ & 8.33 & 7.00 & 6.33 & 6.33 & 8.00 & 8.17 \\
$\mathrm{G}$ & 6.00 & 7.33 & 7.33 & 7.33 & 6.50 & 6.83 \\
$\mathrm{H}$ & 7.00 & 6.67 & 6.67 & 5.67 & 7.33 & 6.50 \\
$\mathrm{I}$ & 6.00 & 7.33 & 7.33 & 7.33 & 6.50 & 6.83 \\
$\mathrm{~J}$ & 7.67 & 5.67 & 6.33 & 6.67 & 7.67 & 8.17 \\
$\mathrm{~K}$ & 7.67 & 7.33 & 6.67 & 6.67 & 7.67 & 8.17 \\
$\mathrm{~L}$ & 8.00 & 7.67 & 7.00 & 7.00 & 8.00 & 8.50 \\
$\mathrm{M}$ & 8.00 & 6.33 & 5.67 & 6.67 & 7.67 & 8.33 \\
$\mathrm{~N}$ & 8.00 & 8.00 & 7.67 & 7.67 & 7.67 & 8.33 \\
$\mathrm{O}$ & 7.87 & 7.67 & 7.00 & 7.00 & 8.00 & 8.50 \\
$\mathrm{P}$ & 8.67 & 7.67 & 7.00 & 6.67 & 7.67 & 8.33 \\
$\mathrm{Q}$ & 8.67 & 8.33 & 7.67 & 7.33 & 7.00 & 7.67 \\
$\mathrm{R}$ & 9.00 & 7.00 & 7.33 & 7.67 & 7.33 & 8.17 \\
$\mathrm{~S}$ & 9.00 & 6.67 & 5.67 & 5.67 & 7.00 & 8.00 \\
$\mathrm{~T}$ & 8.00 & 7.33 & 7.67 & 7.33 & 6.67 & 7.50 \\
$\mathrm{U}$ & 7.67 & 7.67 & 7.33 & 7.33 & 7.00 & 7.17 \\
$\mathrm{~V}$ & 8.00 & 8.00 & 6.67 & 8.00 & 7.00 & 8.00 \\
$\mathrm{~W}$ & 8.00 & 7.33 & 6.67 & 7.00 & 7.00 & 8.00 \\
$\mathrm{X}$ & 7.33 & 7.67 & 7.67 & 7.67 & 7.33 & 7.67 \\
$\mathrm{Y}$ & 6.67 & 7.67 & 7.33 & 7.33 & 6.82 & 7.17 \\
$\mathrm{Z}$ & 8.33 & 7.00 & 7.33 & 7.33 & 7.33 & 7.50 \\
$\mathrm{~A}_{1}$ & 6.00 & 7.33 & 7.33 & 7.33 & 6.82 & 6.83 \\
$\mathrm{~B}_{2}$ & 7.00 & 6.67 & 6.67 & 5.67 & 6.00 & 6.50 \\
$\mathrm{Control}$ & 10.00 & 9.00 & 8.50 & 8.67 & 8.33 & 9.67 \\
\hline & & & & & &
\end{tabular}

\section{B. Discussion}

\section{Proximate compositions of composite bread samples}

The moisture content of the bread samples decreased significantly as the substitution of the cocoyam flour level increased. The highest value of moisture content was obtained in bread sample $\mathrm{P}$, with $95-5 \%$ wheat- cocoyam composite flour, while the lowest value was observed in bread sample G, of $85-15 \%$ wheat-cocoyam flour (Table IV). This finding agrees with that reported by [2] and [17] but differs from studies reported by [18] and [19]. They reported that moisture content of their composite breads increased with increase in levels of non-wheat flour. This phenomenon can be linked to the higher water holding ability of the nonwheat flour as compared to the wheat flour according to [20].

The reduction observed in the protein content of the samples as the cocoyam flour substitution level (Table IV) may be attributable to the fact cocoyam has low protein content. The lowest protein content was observed in sample C, processed from $85 \%-15 \%$ wheat- cocoyam flour blend; while the highest protein content was observed in sample $\mathrm{W}$, processed from 95\%-5\% wheat-cocoyam flour blend, respectively. Roots and tubers have been reported to be low in protein contents thus limiting their extensive utilization.

The rise observed in the crude fibre content could be as a result of the fact that the $100 \%$ wheat flour bread had the lower fibre content values $(0.58 \%)$ when compared with the wheat-cocoyam composite flour breads. Fibre is a source of roughage which helps digestion [21].

There was a noticeable increment in the ash content of the composite bread samples from 0.48 to $0.96 \%$ with increase in the levels of cocoyam flour substitution (from 5 to $15 \%$ ). This rise in ash content could be attributed to the higher quantities of ash in the cocoyam flour as compared to wheat flour. This agrees with the findings of [22] who reported an increase in the ash content of wheat-cassava bread.

Samples I and R contained the lowest (4.43\%) and highest (7.81\%) fat contents which were produced from $85 \%-15 \%$ wheat-cocoyam flour blend and 95\%-5\% wheat-cocoyam 
flour blends, respectively. The fat content decreased with increase in the wheat and cocoyam flour formulation (Table 4), this could be due to their low-fat contents as reported by [17]. Fat bestows tenderness, moistness, flavour, colour, and anti-staling qualities in confectionary products.

The highest carbohydrate content $(71.31 \%)$ was observed in sample $\mathrm{D}$, with a proportion of $85 \%$ wheat and $15 \%$ cocoyam flour while the least value of carbohydrate was observed in bread sample $\mathrm{M}$, with the proportion of $95 \%$ wheat and 5\% cocoyam flour (Table IV). According to [23], cocoyam contains carbohydrate in the form of starch. [17] also reported an increase in carbohydrate content due to blending with cocoyam flours. Carbohydrate pre-dominates all solid nutrients in roots and tubers [24].

\section{Sensory evaluation}

The sensory properties of the bread samples are presented in Table 5. The evaluation was based on a nine-point hedonic scale. The properties: taste, crust colour, crumb colour, flavour, texture, and overall acceptability of the composite breads were compared with the control bread (100\% wheat). Significant statistical differences were observed within each attribute. This shows that these differences observed were as a result of the substitution levels of the wheat and cocoyam flours as observed by the panellists and as it affected their preferences.

For taste, it was observed that the $100 \%$ wheat flour bread, $5 \%$ and $10 \%$ cocoyam flour substituted bread, respectively, were the most preferred (Table V). Bread with higher proportion of wheat $(95 \%)$ and lower proportion of cocoyam flour $(5 \%)$ scored the highest, which agrees with the findings of [11] and [25]. Nevertheless, increasing cocoyam flour from 5 to $15 \%$ did not show any significant difference in the taste of the bread as this reflects the bland taste associated with cocoyam flour. [1], [26] and [27] all reported similar findings.

Flavour contributes greatly to the acceptability or otherwise of a product according to [28]. The sensory evaluation revealed that the most preferred bread samples were the $100 \%$ wheat flour bread, $5 \%, 10 \%$ and $15 \%$ cocoyam flour substituted breads respectively (Table VI). Food flavour results from subtle interactions between taste and aroma, which gives a favourable or unfavourable sensory experience to a consumer [29]. It is the flavour of a food that majorly determines whether it will be accepted or rejected, despite the fact that its appearance elicits the initial response.

For the bread crust colour, the $100 \%$ wheat flour bread and the $5 \%$ cocoyam flour substituted bread were the most preferred. As the quantity of cocoyam flour in the bread, baking temperature and time increased, the bread became very dark brown in colour. Table $\mathrm{V}$ shows that higher ratings were given to the bread products having lower proportions of cocoyam flour. It was observed that the crust colour of the following bread products: $100 \%$ (wheat flour bread), N (5\% cocoyam flour bread), U (5\% cocoyam flour bread), A (12.48\% cocoyam flour bread), T, (10\% cocoyam flour) and $\mathrm{D}$ (15 cocoyam flour bread) were given high rating at baking temperature of $235^{\circ} \mathrm{C}$ and time of $35 \mathrm{~min}$, respectively. The brownish bread appearance could be attributed to the high fibre content in the bread [30]. According to [28], colour is an important parameter when assessing baked bread.
For crumb colour, it was observed that $100 \%$ wheat flour bread is the most acceptable (Table V) followed by $5 \%$ substitution of cocoyam flour composite bread samples, while samples with higher proportion cocoyam flour showed the least preference in terms of crumb colour. As the proportion of cocoyam flour increased, the acceptance of crumb colour decreased.

The texture of the composite bread samples decreased as the proportion of cocoyam flour in the composite flour blend increased. This may be attributed to the high fibre content of the bread. It was observed that higher proportions of cocoyam flour (15\%) gave low scores on texture (Table V). [13] reported that high substitution levels of other flours to wheat flour reduces the elastic properties of wheat flour dough which leads to low gas retaining properties during fermentation which in turn reduces the texture quality of the final bread.

A similar trend as observed in the other sensory attributes was observed for the overall rating; $100 \%$ wheat flour bread, $5 \%, 10 \%$ and $15 \%$ cocoyam flour substituted breads were the most desired products overall respectively.

The results obtained from this study agrees with the findings reported by [31] in which they partially replaced wheat flour with flours from tubers. It was observed that at substitution levels with cocoyam flour beyond $15 \%$, preference decreased. The use of cocoyam starch in cookies production at 5 and $10 \%$ levels respectively were reported by [32] has having desirable sensory attributes. [31], equally reported that blending sweet potato flour with wheat flour up to $20 \%$ substitution level, produced confectionaries with improved functional properties. [33] reported that cassava and cocoyam flour can be used to replace wheat flour up to $30 \%$ in the production of rock cakes.

\section{CONCLUSIONS}

Studies were conducted using Central composite design for the production of cocoyam flour. Response surface methodology (RSM) was used in estimating the effect of three independent variables namely, blanching time(X1), drying temperature(X2) and drying time (X3) on the proximate, functional, and ant-nutritional properties of cocoyam flour.

In this study, partial substitution of wheat flour with cocoyam flour was possible and bread samples produced from this combination up to $15 \%$ supplementation with cocoyam flours were acceptable. Consequently, the utilization of cocoyam flour as partial substitution with wheat flour should be further investigated for confectionary purposes. This will help to expand the utilization options for this underutilized crop and make it more popular. Thereby reducing the dependence on wheat flour which will invariably lead to reduced cost of confectionary products in the long run.

\section{ACKNOWLEDGMENT}

The authors would like to thank the technologists in the Agricultural and Bioresources Engineering Laboratory. 


\section{REFERENCES}

[1] Dewettinck K, Van Bockstaele F, Ku“hne B, Van de Walle D, Courtens TM, Gellynck X. Nutritional value of bread: Influence of processing, food interaction and consumer perception. Review. J Cereal Sci. 2008, 48: 243-257.

[2] Mepba, H. D., Eboh, L., and Nwaojigwa, S. U. Chemical composition, functional and baking properties of wheat-plantain composite flours. African Journal of Food Agriculture, Nutrition and Development. 2007, 7(1): 1-22.

[3] Abdelghafor, R.F., Mustafa, A.I., Ibrahim, A.M.H., Krishnan, P.G. Quality of bread from composite flour of sorghum and hard white winter wheat. Adv. J. Food Sci. Technol. 2011, 3: 9-15.

[4] Edema, M., Sanni, L.O., Sanni, A.I. Evaluation of maize-soybean flour blends for sour maize bread production in Nigeria. Afr. J. Biotechnol. 2005, 4(9): 911-918.

[5] Onyeku, O.M., Kupoluyii, C.F., Osibanjo, A.A., Orji, C.N., Ajuebor, F.N., Ajiboshin, I.O. and Asiru, W.B. An economic assessment of commercial production of $10 \%$ cassava- wheat composite flour bread. J. Industrial Res. Technol. 2008, 2(1): 20-30.

[6] Owuamanam, C.I. Quality of bread from wheat/cassava flour composite as affected by strength and steeping duration of cassava in citric acid. Nat. Sci. 2007, 5: 24-28.

[7] Seibel, W. Composite flours. In Future of Flour: A Compendium of Flour Improvement. Popper, L (ed). VerlagAgriMedia. 2006, pp. 193 198.

[8] Dendy, D.A.V. Review of composite flour technology in the context of Tanzania. A paper presented at the workshop. Sorghum and millets marketing and utilization, Arusha Tazania, 3-5 May, 1993.

[9] Milligan, E. D., Amlie, J. H., Reyes, J., Garcia, A. and Meyer, B. Processing for production of edible soy flour. Journal American Oil Chemistry Social. 1981, 58: 331.

[10] Sanni, L.O., Christiana, A.B., Silifat, A.S. (2004). Production of instant cassava noodles. J. Food Technol. 2, 83-89.

[11] Noorfarahzilah, M., Lee, J. S., Sharifudin, M. S., Fadzelly, M. A. B., and Hasmadi, M. (2014). Mini Review: Applications of composite flour in development of food products. International Food Research Journal. 2014, 21: 2061-2074.

[12] Mepba, H.D., Deedua, I.W., Aso, S.N. and Banigo, E.B. Functional, rheological and baking properties of wheat breadfruit (Artocarus altilis) composite flour blends. Niger Delta Biologia. 2006, 6: 50-63.

[13] Nwanekezi, E. C. Composite flours for baked products and possible challenges-A review. Nigerian Food Journal. 2013, 31: 8-17.

[14] Chukwu G.O, Nwosu K.I, Madu T.U, Chinaka C, Okoye B. C. Development of Gocing storage method for Cocoyam. Retrieved September 17, 2010, from http://mpra.ub.unimuenchen.de/17444.

[15] Peluola-Adeyemi, O.A., Obi T.E. and Ugbogu, D.I. Effect of temperature and time on the physical properties of bread produced from wheat cocoyam flour using response surface methodology. Journal of Food Technology Research. 2016, 3 (2): 63-71.

[16] Lipi, D., Utpal and C. Runu. Effects of baking conditions on the physical properties of herbal bread using RSM. International Journal of foods, Agriculture and Vertinary Sciences. 2012, 2(2): 106-114.

[17] Eddy, N. O., Udofia, P. G and Eyo, D. Sensory evaluation of wheat/cassava composite Bread and effect of label information on acceptance and preference. African Journal of Biotechnology. 2007, 6 (20): 2415-2418.

[18] Njintang NY., Carl MF., Facho B., Pierre K., and Joel S. Effect of taro Colocasiaesculenta) flour addition on the functional and alveographic properties of wheat flour and dough. Journal of the Science of Food and Agriculture. 2008, 88: 273-279.

[19] Olaoye O. A., Onilude A.A., and Idowu O. A. Quality characteristics of bread produced from composite flours of wheat, plantain and soybeans. African Journal of Biotechnology. 2006, 5 (11): 1102-1106.
[20] Tekle, A. The effect of blend proportion and baking condition on the quality of cookie made from taro and wheat flour blend, School of graduate studies, Addis Ababa University. 20http://etd.aau.edu.et/dspace/bitstream/123456789/2882/1/Abent's.p df (Accessed on 20/11/2020).

[21] Marer, E. and Martin, A. Fibre feast lowers cancer risk, Health (Time Inc. Health); Sep 2003, Vol. 17 Issue 7, p. 58.

[22] Masamba, K and Jinazali, H. Effect of cassava flour processing methods and substitution level on proximate composition, sensory characteristics and overall acceptability of bread made from wheatcassava flour blends. Afr J Food Agri Nutr Develop; 2014, 14: 21902203.

[23] Onyeike, E. N., Akaninwor, J. O., and Jonathan, C. I. Effect of heat processing on the proximate composition and energy values of selected Nigerian staple foods from oil producing areas of the Niger delta. Nigerian Society for Experimental Biology. 2008, 20 (1): 1-9.

[24] Okon, B. I., Obi M. B and Ayuki, A.A. Performance of Quails (Coturnix Japonica) Feed Graded Levels of Boiled sun-dried Taro Cocoyam (Colocosia esculenta) as Replacement for maize. Agricultural Journal. 2007, 2 (6): 654-657.

[25] Aniedu, C. Development of secondary food forms of cocoyams (Colocasia spp). J. Agric. For. Soc. Sci. 2006, 4(2): 126-130.

[26] Ibebuchi, C.E., Uzoegbu, J.O. Potential of wheat-cocoyam flour blends in biscuit making. 26th Annual NIFST conference. 2002, Nov. $4-8$, Owerri, pp 37-38.

[27] Dhingra, S. and Jood, S. Organoleptic and nutritional evaluation of wheat breads supplemented with soybean and barley flour. Journal of Food Chemistry 2004, 77: 479-488.

[28] Abu-Salem, F. M. and Abou-Arab, A. A. Effect of supplementation of Bambara groundnut (Vigna subterranean L.) flour on the quality of biscuits. African Journal of Food Science 2011, 5(7): 376-383.

[29] Asumugha, V. U. and Uwalaka, B. C. Chemical and organoleptic evaluation of snacks developed from cocoyam (Colocasia esculenta, Xanthosoma mafafa) and wheat (Triticum spp) composite flours. Nigerian Agricultural Journal. 2010, 31, 78-88.

[30] Hu, G. H., Yang, F, Ma, Z and Zhou Q. Development of research and application of rice bran dietary fibre. China Food Additive. 2007, 84(5):80-85.

[31] Adeleke, R. O., and Odedeji, J. O. Functional properties of wheat and sweet potato flour blends. Pak. J. Nutr., 2010, 9: 535-538.

[32] Ojinaka, M.C., Akobundu, E.N.T. and Iwe, M.O. Cocoyam starch modification effects on functional, sensory and cookies qualities. Pakistan Journal of Nutrition 2009, 8: 558-567.

[33] Sanful, R. E and Darko, S. (2010). Production of Cocoyam, Cassava and Wheat Flour Composite Rock Cake. Pakistan Journal of Nutrition 2010, 9 (8): 810-814.

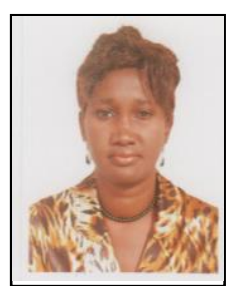

Dr. B. A. Orhevba is an Associate Professor of Agricultural Engineering. Her area of specialization is crop processing and storage, food packaging, storage stability of packaged foods, extraction, and characterization of oil from underutilized seeds, development of product from underutilized seeds and development of crop processing equipment. She is a registered member of ASABE (The American Society of Agricultural and Biological Engineers), COREN (Council for the regulation of Engineering in Nigeria), NSE (Nigerian Society of Engineers) among others. She lectures at the Federal University of technology, Minna, Nigeria. She has many undergraduate and post graduate supervisions to her credit and has published many papers in highly reputable National and International Journals. 